\title{
HUBUNGAN TINGKAT PENDIDIKAN IBU DAN SUMBER AIR MINUM DENGAN KEJADIAN STUNTING PADA BALITA DI WILAYAH KERJA UPT. PUSKESMAS PALANGKAU TAHUN 2021
}

\author{
RELATIONSHIP BETWEEN MATERNAL EDUCATION LEVEL AND DRINKING \\ WATER SOURCES WITH THE INCIDENCE OF STUNTING IN CHILDREN UNDER \\ FIVE IN THE UPT WORKING AREA PUSKESMAS PALANGKAU IN 2021
}

\author{
Edy Ariyanto ${ }^{1 *}$, Fahrurazi ${ }^{2}$, Muhammad Amin ${ }^{3}$ \\ 1,2,3Fakultas Kesehatan Masyarakat, Universitas Islam Kalimantan (UNISKA) MAB \\ Banjarmasin
}

Jl. Adhyaksa. No.2. Kota Banjarmasin, Kalimantan Selatan. Indonesia

* Email:edy.ariyanto777@gmail.com

\begin{abstract}
Stunting is a condition of malnutrition associated with insufficient nutrition in 1000 HPK (First Day of Birth) and the influence of an unhealthy environment, so it is called a chronic nutritional problem. The purpose of this study was to determine the relationship between maternal education level and drinking water sources with the incidence of stunting in children under five in the UPT working area. Puskesmas Palangkau, Kapuas Murung District, Kapuas Regency, Central Kalimantan in 2021. This type of research is quantitative using a cross sectional design and sampling using the Total Sampling technique as many as 56 respondents. Analysis of research data using Chi-Squre Test with ( $a=0.05)$. The results showed that 26 children under five (46.4\%) suffered from stunting, 39 mothers (69.6\%) had a low level of education, while 37(66.1\%). The results of the Chi-Squre Test showed that there was a relationship between the mother's level of education $(P-V a l u e=0.002)$, drinking water sources $(P$ Value $=0.003$ ) and the incidence of stunting in children under five in the working area of the UPT Puskesmas Palangkau, Kapuas Murung District, Kapuas Regency, Central Kalimantan in 2016. 2021. It is hoped that it will raise awareness of mothers about the importance of providing clean drinking water to toddlers.
\end{abstract}

Keywords: drinking water sources; maternal education level; Stunting incidence,

\begin{abstract}
ABSTRAK
Stunting yakni bagian dari keadaan malnutrisi yang berhubungan dengan ketidak cukupan zat gizi pada 1000 HPK (Hari Pertama Kelahiran) dan pengaruh Lingkungan yang tidak sehat sehingga disebut masalah gizi yang bersifat kronis. Tujuan pada penelitian adalah guna mengetahui hubungan tingkat pendidikan ibu dan sumber air minum dengan kejadian stunting pada balita di wilayah kerja UPT. Puskemas Palangkau Kecamatan Kapuas Murung Kabupaten Kapuas Kalimantan Tengah Tahun 2021. Jenis penelitian ini yaitu kuantittatif dengan memakai desain cross secttional dan pengambilan sampel memakai teknik Total Sampling sebanyak 56 responden. Analisi data penelitian memakai Uji Chi-Squre dengan ( $\mathrm{a}=$ 0,05). Hasil penelitian menunjukkan maka 26 balita $(46,4 \%)$ menderita Stunting, tingkat pendidikan ibu yang rendah sebanyak $39 \mathrm{ibu}(69,6 \%)$, sedangkan yang mengunsumsi sumber air minum tidak bersih sebanyak 37(66,1\%). Hasil Uji Chi-Squre menunjukkan maka ada hubungan antara tingkat pendidikan ibu (P-Value $=0,002)$, sumber air minum (P-Value $=0,003)$ dengan kejadian stunting pada balita di wilayah kerja UPT Puskesmas Palangkau Kecamatan Kapuas murung Kabupaten Kapuas Kalimantan Tengah tahun 2021. Diharapkan bisa menumbuhkan kesadaran ibu akan pentingnya pemberian air minum yang bersih kepada balita.
\end{abstract}

Kata Kunci: Kejadian stunting; tingkat pendidikan ibu; sumber air minum 


\section{PENDAHULUAN}

Stunting suatu permasalahan yang tengah tertantang pada dunia khususnya di Negara miskin dan berkembang. Dari tingginya prevelenssi stunting di dunia, ini bisa disimak dari persentase kejadian stunting di dunia pada tahun 2017 yang mencapai $22,2 \%$, Setengah dari jumlah anak dengan stunting berada di Asia (55\%) dan sepertiga berada di Afrika (39\%) (7). Rata-rata prevalenssi balita stunting di Indonesia tahun 2005-2017 yaitu 36,4\%. Berlandaskan hasil PSG tahun 2015 yang diagendakan untuk pemantauan dan evaluasi kegiatan dan capaian program pemerintah dalam mengurangi prevalenssi balita stunting di Indonesia, yang mencapai angka sebanyak 29\%. Angka ini pernah mengalami pengurangan pada tahun 2016 menjadi 27,5\%. Namun meningkatnya prevalenssi balita pendek kembali terjadi menjadi 29,6\% pada tahun 2017 (4).

Dinas Kesehatan Provinsi Kalimantan Tengah (3) mengakui maka kasus stunting di Provinsi Kalimantan Tengah terjadi di tiga kabupaten yaitu Kotawaringin Timur, Kabupaten Barito Timur dan Kapuas, di mana Prevalenssi yang terbesar yaitu di Kabupaten Kotawaringin Timur yaitu sebanyak $48,1 \%$ yang mana terjadi kenaikan dari hasil Riskesdas tahun 2013 yaitu sebanyak 36\% (11). Berdasarkan data Puskesmas Palangkau tahun 2020 menunjukkan kasus stunting sebanyak 16,3\% yang disebabkan oleh beberapa faktor. Maka di semua Desa binaan Puskesmas Palangkau tidak memiliki akses Air bersih dan enam Desa diantaranya belum memiliki Sanitasi (Jamban Sehat). Hal ini dipengaruhi oleh kebiasaan penduduk lokal yang pada garis keturunan mengunsumsi air minum dari sungai untuk kebutuhan sehari - hari serta buang air besar di sungai dan pengetahuan yang minim terhadap Stunting (9).

Dari hasil penelitian yang dilaksanakan sebelumnya, diketahui tingkat pendidikan masyarakat Palangkau lebih dominan pada tingkat dasar yaitu 65 dari total 85 orang atau 69,4\%. Sedangkan perilaku masyarakat Palangkau sebagian warganya masih mengikuti kebiasaan orang bahari yang mengambil air untuk dikunsumsi langsung dari sungai (11). Berlandaskan dari hasil laporan magang yang peneliti lakukan di UPT Puskesmas Palangkau Kecamatan Kapuas Murung Kabupaten Kapuas, diketahui tingkat pendidikan orang tua masih terbilang rendah, serta perilaku masyarakat yang memiliki tradisi turun-temurun mengunsumsi air sungai dan belum memiliki fasilitas sanitasi yang memadai, bagian darinya akses air bersih sehingga mempengaruhi pada kesehatan dan berdampak pada balita stunting. Dengan tradisi masyarakat yang meminum air sungai langsung serta diperkuat dengan keterbatasan sumber air bersih, masyarakat di wilayah kerja Puskesmas Palangkau tepatnya Desa Palangkau Baru dan Palangkau lama hanya memiliki sumber air minum dari sungai, sumur bor dan air isi ulang yang disuplai dari desa lain dengan harga yang cukup mahal, sehingga dengan ekonomi masyarakat yang terbilang rendah lebih banyak memakai sumber air minum dari sungai dibanding air isi ulang maupun sumur bor yang masih berbau.

Penelitian ini bertujuan untuk mengidentifikasi dan menganalisis hubungan tingkat pendidikan ibu dan sumber air minum dengan kejadian stunting pada balita di wilayah kerja UPT Puskemas Palangkau Kecamatan Kapuas Murung Kabupaten Kapuas Kalimantan Tengah Tahun 2021.

\section{BAHAN DAN METODE}

Rancangan penelitian ini memakai desain cross sectional dengan variabel independen yaitu tingkat pendidikan ibu dan sumber air minum sedangkan variabel dependen yaitu kejadian stunting. Populasi pada penelitian ini yaitu ibu yang memiliki balita di desa Palangkau Baru dan Palangkau Lama yang berjumlah 56 orang dari bulan Januari - Desember tahun 2020 hasil dari rekapitulasi pemantauan pertumbuhan balita Puskesmas Palangkau (9). Alasan mengambil total sampling karena menurut Sugiyono jumlah populasi yang kurang dari 100 semua populasi di jadikan sampel penelitian semuanya. Sampel yang diambil dari penelitian ini yaitu 56 orang. 


\section{HASIL DAN PEMBAHASAN}

\section{Analisis Univariat}

Tabel 1. Distribusi Frekuensi

\begin{tabular}{|c|c|c|}
\hline Variabel & $\mathbf{n}$ & $\%$ \\
\hline \multicolumn{3}{|l|}{ Kejadian Stunting } \\
\hline Stunting & 26 & 46,4 \\
\hline Tidak Stunting & 30 & 53,6 \\
\hline \multicolumn{3}{|l|}{ Pendidikan Ibu } \\
\hline Rendah & 39 & 69,6 \\
\hline Tinggi & 17 & 30,4 \\
\hline \multicolumn{3}{|l|}{ Sumber Air Minum } \\
\hline Tidak Bersih & 37 & 66,1 \\
\hline Bersih & 19 & 33,9 \\
\hline Total & 56 & 100 \\
\hline
\end{tabular}

Berlandaskan tabel 1 menunjukkan maka sebagian besar balita tidak mengalami stunting sebanyak sebanyak 53,6\%, sedangkan balita stunting sebanyak 46,4\%. Distribusi Frekuenssi Berlandaskan Tingkat Pendidikan Ibu di Desa Palangkau Baru dan Palangkau Lama wilayah kerja UPT. Puskesmas Palangkau. Berlandaskan tabel hasil menunjukkan maka ibu yang berpendidikan rendah 39 orang $(69,6 \%)$, Sedangkan yang berpendidikan tinggi 17 orang (30,4\%). maka yang memakai sumber air minum tidak bersih 37 responden $(66,1 \%)$, Sedangkan yang memakai sumber air minum yang bersih 19 responden $(33,9 \%)$.

Tabel 2. Hubungan antara Variabel Tingkat Pendidikan Ibu dan Sumber Air Minum dengan kejadian Stunting pada Balita di Wilayah Kerja UPT. Puskesmas Palangkau

\begin{tabular}{|c|c|c|c|c|c|c|c|}
\hline Variabel & \multicolumn{4}{|c|}{ Kejadian Stunting } & \multicolumn{2}{|c|}{ Jumlah } & P-value \\
\hline \multirow[t]{2}{*}{ Tingkat Pendidikan } & \multicolumn{2}{|c|}{ Stunting } & \multicolumn{2}{|c|}{ Tidak Stunting } & \multirow[b]{2}{*}{$\mathbf{n}$} & \multirow[b]{2}{*}{$\%$} & \multirow{4}{*}{0,002} \\
\hline & $\mathbf{n}$ & $\%$ & $\mathbf{n}$ & $\%$ & & & \\
\hline Rendah & 24 & 61,5 & 15 & 38,5 & 39 & 100 & \\
\hline Tinggi & 2 & 11,8 & 15 & 88,2 & 17 & 100 & \\
\hline Sumber Air Minum & & & & & & & 0,003 \\
\hline Tidak Bersih & 23 & 62,2 & 14 & 37,8 & 37 & 100 & \\
\hline Bersih & 3 & 15,8 & 16 & 84,2 & 19 & 100 & \\
\hline Total & 26 & 46,4 & 30 & 53,6 & 56 & 100 & \\
\hline
\end{tabular}

Berlandaskan tabel 2 menunjukkan maka ibu dengan tingkat pendidikan rendah dan balita mengalami stunting sebanyak 24 orang $(61,5 \%)$, sedangkan ibu dengan tingkat pendidikan tinggi dan balita mengalami stunting sebanyak 2 orang (11,8\%). Hasil uji Pearson Chi-squre diperoleh nilai $\mathrm{P}$-value $=0,002<\mathrm{a}=0,05$ maka Ho ditolak, artinya ada hubungan tingkat pendidikan dengan kejadian stunting pada balita di Desa Palangkau wilayah kerja UPT Puskesmas Palangkau tahun 2021 dan proporsi penggunaan sumber air minum tidak bersih dan balita mengalami stunting sebanyak $23(62,2 \%)$, sedangkan penggunaan sumber air minum bersih dan balita mengalami stunting sebanyak 3 orang $(15,8 \%)$. Hasil uji Pearson ChiSqure diperoleh nilai P-value $=0,003<\mathrm{a}=0,05$ maka Ho ditolak, artinya ada hubungan penggunaan sumber air minum dengan kejadian stunting pada balita di Desa Palangkau Wilayah Kerja UPT Puskesmas Palangkau tahun 2021.

\section{PEMBAHASAN}

Hasil menunjukkan maka ibu yang berpendidikan rendah 39 orang $(69,6 \%)$, Sedangkan yang berpendidikan tinggi 17 orang $(30,4 \%)$. Berlandaskan data menunjukkan maka ibu balita 
dengan pendidikan rendah masih mendominasi di ke dua desa dibandingkan dengan yang berpendidikan tinggi sehingga berpengaruh terhadap pengetahuan ibu terhadap stunting, adapun tingkat pendidikan rendah dikarnakan oleh fasilitas yang memang masih terbatas, yaitu TK, SD, dan SMP sehingga untuk melanjutkan pendidikan yang lebih tinggi harus ke kota atau luar daerah, oleh karena itu sebagian banyak penduduk desa lebih memilih untuk bekerja. Maka pada dasarnya pendidikan itu sangat berhubungan erat dengan pengetahuan, tingkat pendidikan yang lebih tinggi akan memudahkan seseorang untuk menyerap informasi dan mengimplementasikannya dalam perilaku dan gaya hidup sehari- hari, khususnya dalam hal kesehatan (2). maka dari itu untuk menghindari hal tersebut maka diperlukan sosialisasi kepada ibu-ibu yang mempunyai balita atau intervensi tentang penyebab dan pencegahan stunting, guna meningkatkan pengetahuan ibu dan status gizi balita.

Hasil menunjukkan maka yang memakai
sumber air minum tidak bersih 37 responden(66,1\%), Sedangkan yang memakai sumber air minum yang bersih 19 responden(33,9\%).Berlandaskan hasil menggambarkan maka masih banyak responden yang memakai air minum dari sumber yang tidak bersih, yaitu sumber air dari sungai barito dengan kondisi fisik sangat keruh yang diakibatkan oleh aktivitas kapal tongkang pengangkut batubara, ditambah sungai yang langsung terhubung ke saluran irigasi food state dan perusahaan sawit, dan hasil observasi dilapangan diketahui sebagia banyak ibu masih memberikan anaknya susu tidak memakai Dot serta faktor ekonomi yang rendah membuat susahnya untuk menemukan air yang bersih. Diketahui maka dikedua desa ini belum memiliki fasilitas air bersih seperti PDAM dan lainnya, sehingga untuk menemukan air bersih warga harus membeli dari desa lain dengan harga yang bervariasi dan akses yang jauh hanya bisa diakses melalui sungai dengan memakai kelotok, karna itu masih banyak warga yang mengunsumsi air dari sungai dimana kualitas air tersebut sangat keruh. mikrobioogis yaitu persyaratan yang harus dipenuhi sebagai air bersih (5).

\section{Hubungan Tingkat Pendidikan Ibu dengan kejadian Stunting pada Balita}

Berdasarkan penelitian menunjukkan maka ibu dengan tingkat pendidikan rendah dan balita mengalami stunting sebanyak $61,5 \%$, sedangkan ibu dengan tingkat pendidikan tinggi dan balita mengalami stunting sebanyak $11,8 \%$. Hasil uji Pearson Chi-squre diperoleh nilai P-value $=0,002<\mathrm{a}=$ 0,05 maka Ho ditolak, artinya ada hubungan tingkat pendidikan dengan kejadian stunting pada balita di Desa Palangkau wilayah kerja UPT Puskesmas Palangkau tahun 2020 (8). Sebagian besar ibu balita dengan pendidikan rendah, sehingga pengetahuan dan wawasan maupun informasi masih kurang terhadap kejadian stunting, oleh karena itu untuk mengantisipasi hal tersebut diperlukan edukasi, sosialisasi atau intervensi tentang penyebab dan pencegahan stunting, guna meningkatkan penegetahuan ibu dan status gizi balita. Hal ini searah dengan penelitian yang dilaksanakan Irawatie, (6) tentang Faktor-Faktor Yang Berhubungan Dengan Kejadian Stunting Pada Balita 12-59 Bulan Di Wilayah Kerja Puskesmas Parenggean Tahun 2020, menunjukkan ada hubungan antara tingkat pendidikan ibu dengan kejadian stunting diperoleh P-value $=0,001$.

\section{Hubungan Sumber Air Minum dengan kejadian Stunting pada Balita}

Berlandaskan hasil penelitian menunjukkan maka proporsi penggunaan sumber air minum tidak bersih dan balita mengalami stunting sebanyak $62,2 \%$, sedangkan penggunaan sumber air minum bersih dan balita mengalami stunting sebanyak 15,8\%. Hasil uji Pearson Chi-Squre diperoleh nilai $P$-value $=0,003<\mathrm{a}=0,05$ maka Ho ditolak, artinya ada hubungan penggunaan sumber air minum dengan kejadian stunting pada balita di Desa Palangkau Wilayah Kerja UPT. Puskesmas Palangkau tahun 2021(8). Sebagian banyak ibu balita masih mengunsumsi sumber air minum yang keruh yaitu berasal dari sungai Barito, sungai tersebut memiliki air yang keruh dikarnakan banyaknya aktivitas kapal besar seperti tongkak batu bara, saluran anak sungai dari trans dan perusahaan sawit sehingga berdampak bagi kesehatan balita khususnya balita mengalami stunting. Bagian dari faktor yang membuat pertumbuhan balita menjadi lambat yaitu 
dikarnakan sering sakit atau menderita diare yang disebabkan oleh mengunsumsi air sungai secara langsung. Sumber air minum yakni bagian dari faktor yang menyebabkan stunting, hal ini disebabkan karena sumber air minum di Desa Palangau Baru dan Palangkau Lama dari sungai yang keruh. Penelitian ini searah dengan penelitian yang dilaksanakan (12) tentang Faktor resiko stunting pada balita (24-59 bulan) di Sumatera, menunjukkan ada hubungan antara Sumber air minum dengan kejadian stunting diperoleh $\mathrm{P}$ value $=0,01$.

\section{KESIMPULAN DAN SARAN}

Berdasarkan kesimpulan pada penelitian ini adalah adanya hubungan Tingkat Pendidikan Ibu Dan Sumber Air Minum Dengan Kejadian Stunting Pada Balita Di Wilayah Kerja UPT terdapat ada hubungan tingkat pendidikan dan penggunaan sumber air bersih dengan kejadian stunting pada balita di Desa Palangkau wilayah kerja UPT Puskesmas Palangkau tahun 2021. Saran untuk dapat meningkatkan pemberian informasi dan sosialisasi kepada masyarakat mengenai stunting dengan cara promotif atau memberikan penyuluhan tentang sumber air minum terhadap kejadian stunting untuk meningkatkan kesadaran dan pengetahuan masyarakat serta memberikan perhatian khusus pada anak-anak yang mengalami stunting dan diperlukan intervensi fokus kesehatan kepada ibu agar lebih meningkatkan status gizi balita dan hasil penelitian ini dapat dijadikan referensi atau perbandingan bagi penelitian selanjutnya, dan diharapkan meneliti variabelvariabel lain seperti perilaku hygiene, pendapatan keluarga dan sanitasi lingkungan.

\section{UCAPAN TERIMAKASIH}

Pada kesempatan ini penulis ingin mengucapkan terima kasih dan penghargaan yang setinggi-tingginya kepada Meilya Farika Indah, SKM., M. Sc, selaku Dekan Fakultas Kesehatan Masyarakat Universitas Islam Kalimantan Muhammad Arsyad Al- Banjari Banjarmasin dan Nano, S. Kep, selaku Kepala UPT. Puskesmas Palangkau serta semua pihak yang telah banyak berpartisipasi.

\section{DAFTAR PUSTAKA}

1. Arikunto, S. 2010.Manajemen Penelitian. Jakarta: Rineka Cipta.

2. Dian R. 2020. Hubungan Tingkat Pendidikan Ibu Dan Pemberian Informasi Tentang Stunting Dengan Kejadian Stunting. Kediri

3. Dinkes Provinsi Kalteng. 2018. Profil Kesehatan P rovinsi Kalimantan Tengah Tahun 2018. Palangka Raya

4. Kemenkes RI. 2018. Laporan Hasil Riset Kesehatan Dasar (Riskesdas) Tahun $2018 . \quad$ Jakarta: Kementerian Kesehatan RI Pusat Data dan Informasi

5. Kusnaedi. 2010. persyaratan mikrobiologis. eprints.poltekkesjogja.ac.id/777/4/4 BAB II revisi... . PDF file

6. Irawatie, I. 2020. Faktor-Faktor Yang Berhubungan Dengan Kejadian Stunting Pada Balita 12-59 Bulan Di Wilayah Kerja Puskesmas Parenggean I Tahun 2020. Eprint.uniskabjm.ac.id [diakses 20 Mei 2020]

7. UNICEF. 2018. The state of the world's children 1998. Oxford: Oxford University Press.

8. UPT Puskesmas Palangkau. 2020. Data ePPGBM. Kapuas.

9. UPT Puskesmas Palangkau. 2020. Laporan Pertahun Profil Kesling. Kapuas

10. UPT Puskesmas Palangkau. 2020. Laporan Pertahun Target Dan Pencapaian UpayapenguranganKasus Balita Stunting. Kapuas

11. Riset Kesehatan Dasar (Riskesdas). Prevalensi stunting di Indonesia tahun 2007， 2013， dan 2018. Eprints.undip.ac.id

12. Sri Maulida. 2016. Hubungan Gaya Hidup Dan Pola Makan Dengan Kejadian Hipertensi Di Wilayah Kerja Puskesmas Palangkau Kecamatan Kapuas Murung Kabupaten Kapuas Kalimantan Tengah Tahun 2016. FKM Uniska. Barjarmasin 